\title{
‡USGS
}

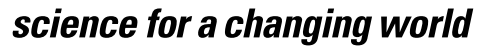

\section{Land-Cover Trends of the Central Basin and Range Ecoregion}

By Christopher E. Soulard

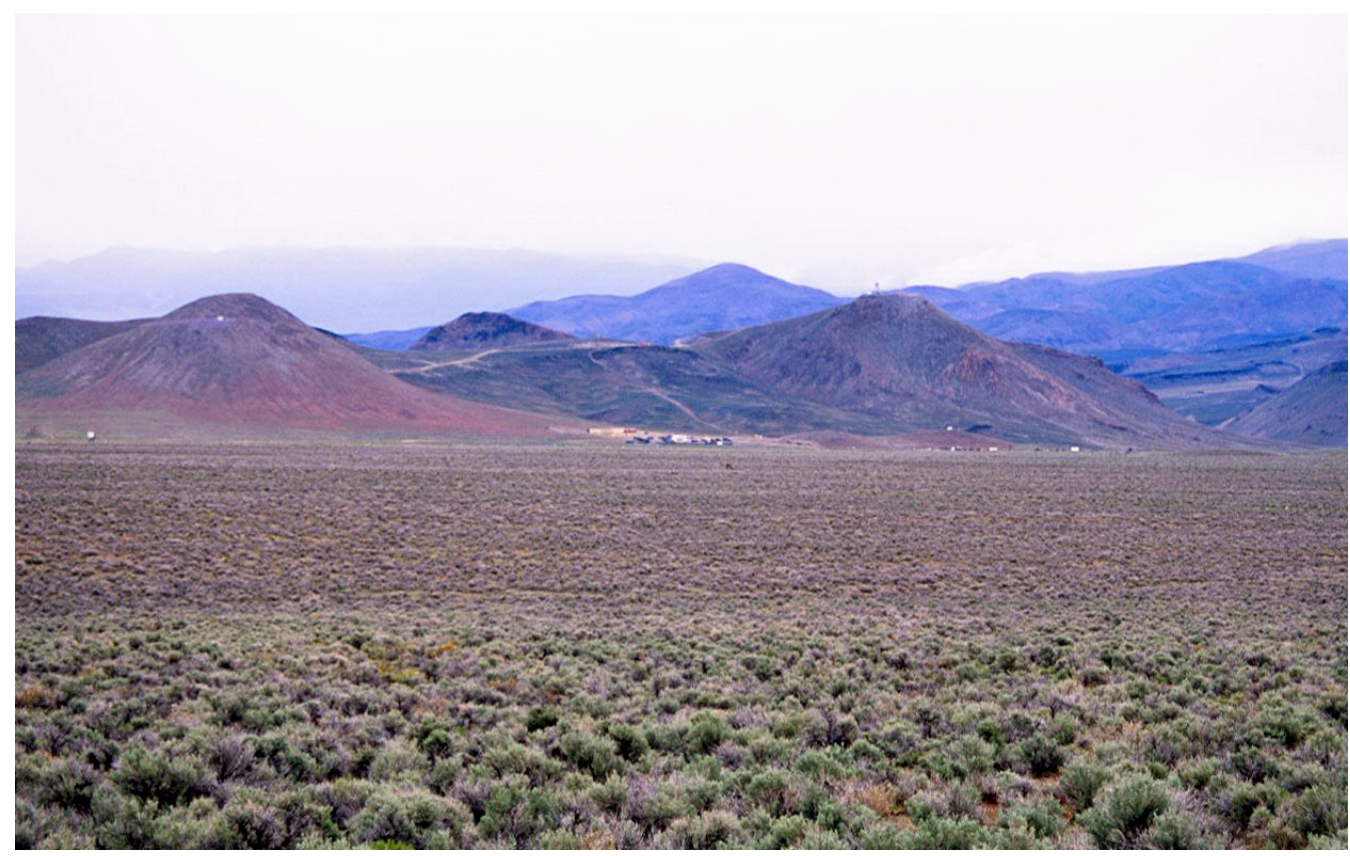

Scientific Investigations Report 2006-5288

U.S. Department of the Interior

U.S. Geological Survey 


\section{U.S. Department of the Interior DIRK KEMPTHORNE, Secretary}

\section{U.S. Geological Survey Mark D. Myers, Director}

\section{U.S. Geological Survey, Reston, Virginia: 2006}

This report and any updates to it are available online at:

http://pubs.usgs.gov/sir2006/5288/

For product and ordering information:

World Wide Web: http//www.usgs.gov/pubprod

Telephone: 1-888-ASK-USGS

For more information on the USGS - the Federal source for science about the Earth, its natural and living resources, natural hazards, and the environment:

World Wide Web: http://www.usgs.gov

Telephone: 1-888-ASK-USGS

Any use of trade, product, or firm names in this publication is for descriptive purposes only and does not imply endorsement of the U.S. Government.

Although this report is in the public domain, permission must be secured from the individual copyright owners to reproduce any copyrighted materials contained within this report.

Cataloging-in-publication data are on file with the Library of Congress (http://www.loc.gov/).

Produced in the Western Region, Menlo Park, California

Manuscript approved for publication, October 18, 2006

Text edited by James W. Hendley II

Layout and design by Judy Weathers

FRONT COVER

Field photo of sagebrush plant community. Sagebrush makes up more than one third of the vegetation in the Central Basin and Range ecoregion. 


\section{Foreword}

The U.S. Geological Survey (USGS) Land Cover Trends research project is focused on understanding the amounts, rates, trends, causes, and implications of contemporary land-use and land-cover (LU/LC) change in the United States. This project is supported by the USGS Geographic Analysis and Monitoring Program in collaboration with the U.S. Environmental Protection Agency (EPA) and the National Aeronautics and Space Administration (NASA).

LU/LC change is a pervasive process that modifies landscape characteristics and affects a broad range of socioeconomic, biologic, and hydrologic systems. Understanding the impacts and feedbacks of LU/LC change on environmental systems requires an understanding of the rates, patterns, and driving forces of past, present, and future LU/LC change. The objectives of the Land Cover Trends project are to (1) determine and describe the amount, rates, and trends of contemporary LU/LC change by ecoregion for the period 1973-2000 for the conterminous United States, (2) document the causes, driving forces, and implications of change, and (3) synthesize individual ecoregion results into a national assessment of LU/LC change.

The Land Cover Trends research team includes staff from the USGS National Center for Earth Resources Observation and Science (EROS), Rocky Mountain Geographic Science Center, Eastern Geographic Science Center, Mid-Continent Geographic Science Center, and the Western Geographic Science Center. Other partners include researchers at South Dakota State University, University of Southern Mississippi, and State University of New York College of Environmental Science and Forestry. 


\section{Contents}

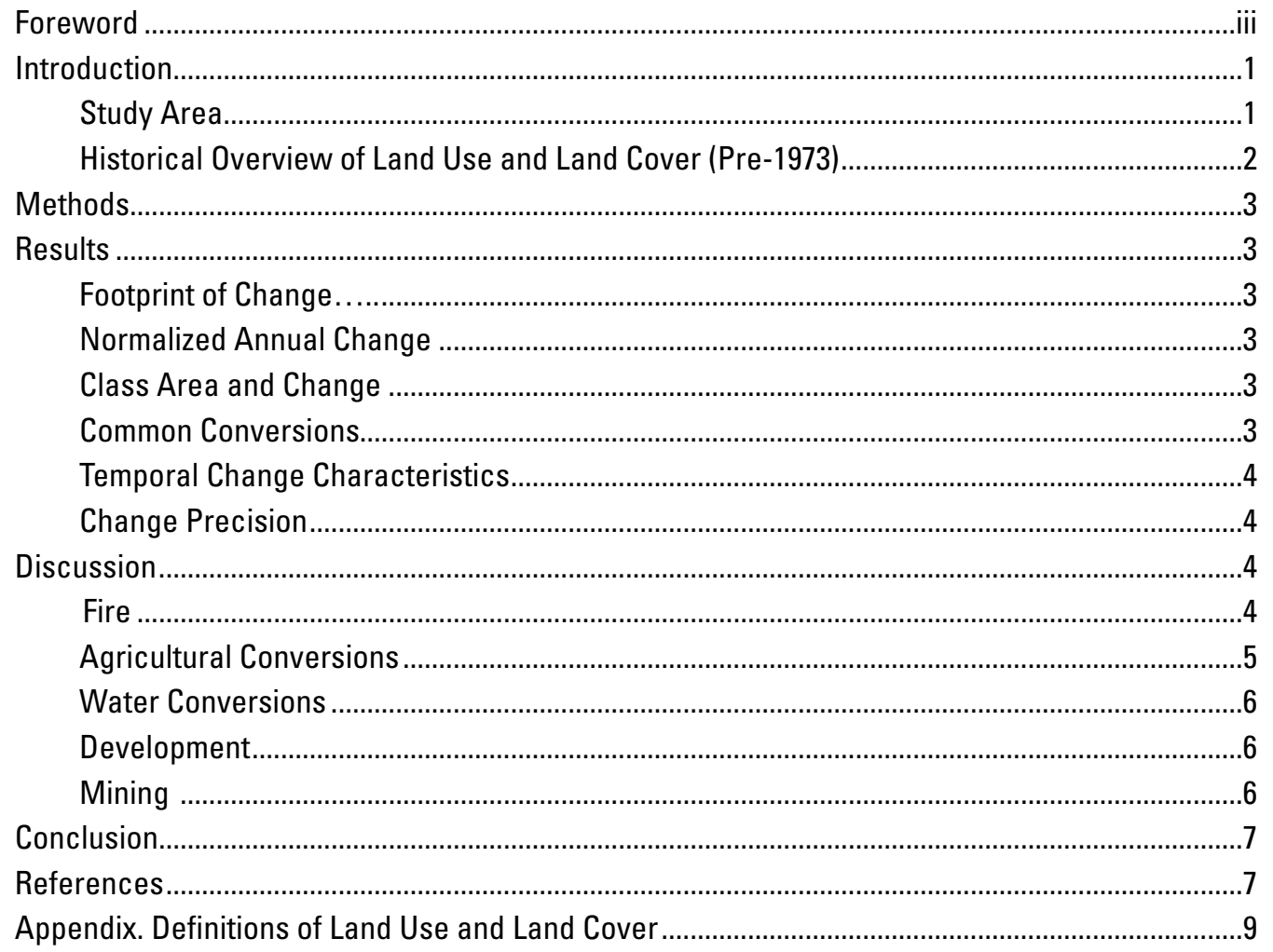

\section{Figures}

1. Location map of the Central Basin and Range Ecoregion ........................................................10

2. Graphic illustrating interrelationship between land use, invasive plants, and fire ....................11

3. Graph illustrating average annual rates of change ............................................................12

4. Graph illustrating gross change by class over the study period .................................................13

5. Example of nonmechanically disturbed classification ...............................................................14

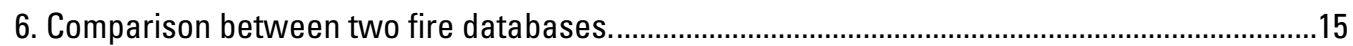

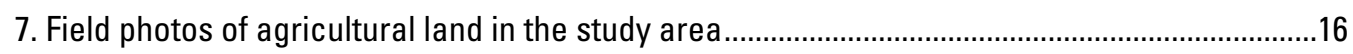

8. Comparison between two development databases. ...............................................................16

9. Field photos of waste facility and downstream drainage in the study area...............................17

10. Field photos illustrating different elements of mining in the study area. ..................................18

\section{Tables}

1. Percent total land area by class over the study period .........................................................19

2. Most common land-cover conversions over the study period .................................................19

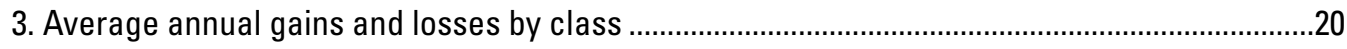

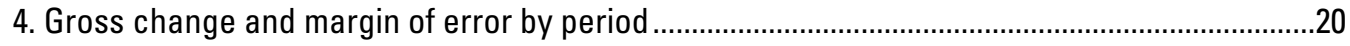




\title{
Land-Cover Trends of the Central Basin and Range Ecoregion
}

\author{
By Christopher E. Soulard
}

\section{Introduction}

This report presents an assessment of land-use/land-cover (LU/LC) change in the Central Basin and Range ecoregion (fig. 1) for the period 1973-2000. The Central Basin and Range ecoregion is one of 84 Level-III ecoregions as defined by the Environmental Protection Agency (EPA, 1999, Omernik, 1987). Ecoregions have served as a spatial framework for environmental resource management and to denote areas that contain a geographically distinct assemblage of biotic and abiotic phenomena including geology, physiography, vegetation, climate, soils, land use, wildlife, and hydrology. The established Land Cover Trends methodology generates estimates of LU/LC change using a probability sampling approach and change-detection analysis of thematic land-cover images derived from Landsat satellite imagery.

\section{Study Area}

The Central Basin and Range Level III ecoregion is similar, yet distinct from the extent of the hydrographic Great Basin (Grayson, 1993). Most of the region is located in Nevada (65.4 percent) and Utah (25.1 percent), but small segments are also located in Idaho (5.6 percent), California (3.7 percent), and Oregon ( 0.2 percent). In all, the Central Basin and Range ecoregion (CBARE) encompasses $343,169 \mathrm{~km}^{2}$ of land bordered on the west by the Sierra Nevada Mountains, on the east by the Wasatch Mountains, on the north by the Northern Basin and Snake River Plain, and on the south by the Mojave Desert and Colorado Plateau (fig. 1). Basin and Range topography characterizes the CBARE: wide desert valleys bordered by parallel mountain ranges generally oriented north-south. There are more than 33 peaks within the CBARE with summits higher than 3,000 meters, but valleys in the region are also high, most with elevations above 1,200 meters (Grayson, 1993). The Great Basin desert, which is encompassed within the CBARE, is one of the four biologically defined deserts in North America in addition to the Mojave, Sonoran, and Chihuahuan (Grayson, 1993). The Great Basin has the coldest climate of these deserts.

The CBARE's high elevation and location between mountain ranges influences regional climate. The Sierra Nevada produces a rain shadow effect that blocks moisture from the Pacific Ocean, whereas the Rocky Mountains create a barrier effect that restricts moisture from the Gulf of Mexico (Rog- ers, 1982). Moisture that manages to reach the CBARE tends to precipitate as rain and snow in higher elevations, primarily over the region's long, parallel mountains (Brussard and others, 1998). Ultimately, any precipitation that falls within the CBARE fails to drain either to the Atlantic Ocean or to the Pacific Ocean (thus the term basin). Instead, precipitation drains to ephemeral or saline lakes via streams, or disappears via evaporation and/or absorption into the soil (Grayson, 1993).

This dry climate and rugged topography proves too harsh for many plant and animal species; however, genetic adaptations to these conditions have led to reasonably high species richness within the CBARE. Furthermore, the significant variation between valleys and peaks has created a variety of habitat niches, which has in turn led to many small, isolated populations of genetically unique plant and animal species throughout the region. According to Grayson (1993), more than 600 species of vertebrates live in the floristic Great Basin, which has a similar areal footprint to the CBARE. Sixty-three of these species have been identified as species of conservation concern due to contracting natural habitats (for example, Centrocerus urophasianus, Vulpes macrotis, Dipodomys ordii, and Phyrnosoma platyrhinos) (Rowland and others,1997, Wisdom and others, 2003).

Ultimately, climate, elevation, soil type, and many anthropogenic variables greatly influence the diversity and distribution of shrubland, grassland, and woodland communities in the CBARE. For instance, the moisture and temperature variability between the mountains and valleys of the CBARE contributes to the vegetation gradation from shrubland to woodland as elevation increases. Lower valleys and playas, which have saline soils and great temperature fluctuations, are predominantly vegetated by scattered Iodine brush (Allenrolfea occidentalis), saltbrush (Atriplex canescens), saltgrass (Distichlis spicata), shadscale (Atriplex confertilfolia), and other drought tolerant shrubs (Rogers, 1982). The soil salinity and lack of moisture in this zone is not very conducive to most agriculture; however, livestock grazing and grain farming have historically contributed to a decline in the already scattered vegetation (Billings, 1951).

The drop in soil salinity and increase in moisture as elevation increases leads to a transition to sagebrush (Artemisia) and grasses just above the shadscale zone. This expanse, called the sagebrush zone, constitutes the largest amount of land in the CBARE (38.7 percent) and is dominated by big sagebrush (Artemisia tridentata) shrubland (Brussard and others, 1998). 
Introduced annual grasses such as cheatgrass (Bromus tectorum) and halogeton (Halogeton glomeratus) also characterize this zone, although native bunchgrasses once thrived amongst sagebrush. Historical fire suppression, adjusted fire frequency following the introduction of annual grasses, and widespread livestock grazing have contributed to contraction of the sagebrush zone (Eiswerth and others, 2006). According to Noss and others (1995), 99 percent of the sagebrush-grass zone has been damaged by livestock, with major damage in 30 percent of the zone.

The subalpine woodlands on the mountain slopes above the sagebrush zone $(\sim 1,500$ meters) are dominated by pinyon pine (Pinus edulis) and juniper communities (for example, Juniperus communis, Juniperus occidentalis, and Juniperus osteosperma). This zone of dense vegetation, made possible by thermal inversions and increased precipitation, is important to a wide variety of isolated animals that rely on this vegetation interface for survival (for example, Eutamias plameri) (Brussard and others, 1998).

Public lands are 76.4 percent of the CBARE, with 59.4 percent managed by the Bureau of Land Management (BLM). Other public land managers include the U.S. Forest Service (USFS) and the National Park Service (NPS). USFS manages 10.8 percent of the CBARE, including the Humboldt-Toiyabe National Forest and the Inyo National Forest. Great Basin National Park and part of Death Valley National Park are the only NPS holdings in the CBARE. Department of Defense (DOD) lands also are a large part of the Federal holdings in the CBARE (3.9 percent), the largest being Nellis Air Force Base (National Atlas of the United States, 2005).

Public land management, military activities, and local government administration account for a large part of the CBARE's economy. Other leading economic sectors include mining and agriculture, both of which have a rich history in the region. The mining sector is dominated by metal mining (for example, gold, copper, and nickel), but nonmetallic mineral (for example, gravel) and fossil fuel extraction also account for a significant number of operational mining establishments (County Business Patterns, 1997). Agricultural production can be primarily characterized by cattle and hay production; however, there are measurable contributions from sheep, alfalfa, and barley production to the agricultural sector (USDA, 2005). The economy is rounded off by manufacturing, which is encapsulated by the processing of these raw mining and agricultural materials, and the service sector, which is growing along with a burgeoning retirement community in the CBARE (Bureau of Economic Analysis, 2000). While mining and agricultural activities are dispersed throughout the CBARE, the remaining sectors of the economy tend to be concentrated in and around the municipalities of the region.

The largest concentrations of population in the CBARE are along the eastern and western borders of the region. The eastern regional boundary encompasses the greater Salt Lake area, whereas the Reno-Sparks-Interstate 395 expanse composes the western regional boundary. In 2000, the largest cities in terms of population were Salt Lake City, Utah (pop. 181,743), Reno, Nevada (pop. 180,480), West Valley, Utah (pop. 108,896), Provo, Utah (pop. 105,166), and 33 other cities with populations greater than 10,000 people (National Atlas of the United States, 2005). Overall, the CBARE has a total population around 2.5 million (U.S. Census Bureau, 2000).

\section{Historical Overview of Land Use and Land Cover (Pre-1973)}

European habitation of the CBARE began in the late 1700s, and ushered in an era of intense natural-resource extraction. This shift in land use-intensity marked the change from a time when people reacted to environmental change to a time when the "environment [primarily] react[ed] to human influence" (Grayson, 1993). Early European immigrants engaged in mineral mining (gold, silver, and copper), livestock grazing, and timber harvesting (Rogers, 1982, University of Nevada Reno, 1999). Between 1860 and 1890, the regional mineral industry flourished via the Comstock Lode, a large silver and gold deposit found east of Mount Davidson, Nevada. This spike resulted in more intense resource exploration and the rise of many boomtown developments across the landscape, such as Goldfield and Tonopah (University of Nevada Reno, 1999). Massive tailing piles and the plethora of ghost towns scattered throughout the CBARE today provide a snapshot of this moment in history.

However, not all of the towns that arose in the mid-1800s experienced a bust after the mines were exhausted and silver prices dropped. Some of the mining cities in the western CBARE (for example, Reno and Carson City) prospered from a steady stream of gold and silver strikes coupled with the businesses that came along with the Pony Express and transcontinental railroad. In the early $20^{\text {th }}$ century, these towns experienced another boom following the legalization of casino gambling in Nevada. Cities that were not entirely dependant on mining, such as Great Salt Lake City (now Salt Lake City), relied on agricultural production as an economic staple in their early stages of urbanization. During World War II, military installations helped invigorate the economies of Salt Lake City and its neighboring communities following the Great Depression (Launius, 2004).

The westward expansion of railroads in the late 1860s brought more settlers, more intense land use, and ultimately led to the introduction or many invasive species in the CBARE (Trimble, 1989). The most notable of these invasive species is cheatgrass (Bromus tectorum), which was introduced by settlers intending to feed domestic livestock by filling areas left void by native plants (Pellant and others, 2004). Cheatgrass and other introduced annuals not only outcompeted native bunchgrasses, but also altered the CBARE's fire regime. In areas that previously burned about every 30 to 70 years, the introduction of cheatgrass increased fire-return intervals to less than 10 years (Pellant and others, 2004). In turn, this led to a significant decline in native sagebrush. 
The agricultural industry intensified the problem for native plants between 1930 and 1960, when vast areas were tilled and seeded with crested wheatgrass (Agropyron desertorum) for livestock, and herbicides were applied to kill native brush varieties (Trimble, 1989). The Sagebrush Rebellion, which was based on reducing Federal influence in state lands, began soon thereafter and spurred changes in state laws towards local control. These changes led to considerable range improvements in the 1980s, which were challenged by many conservation groups (Pellant and others, 2004). Despite the recent shift in public land management towards sagebrush conservation, the interplay between native-plant decline, cheatgrass expansion, and fire continues to be a trend in the CBARE today (fig. 2).

\section{Methods}

Our interpretation team estimated the amount and rates of LU/LC change in the CBARE ecoregion using a stratified random sample of $36100-\mathrm{km}^{2}(10-\mathrm{km}$ by $10-\mathrm{km})$ blocks allocated across the ecoregion (fig. 1). We manually interpreted up to 11 classes of LU/LC (appendix) from five dates (1973, 1980, 1986, 1992, and 2000) of archived Landsat Multispectral Scanner (MSS), Thematic Mapper (TM), and Enhanced Thematic Mapper Plus (ETM+) satellite imagery using a 60-meter minimum mapping unit (MMU). In addition to manual interpretation techniques, we used historical aerial photographs, topographic maps, and various ancillary data sources to aid in image interpretation. Our LU/LC mapping effort yielded five individual dates and four discrete periods for analysis. We then used post-classification comparison of the five dates of thematic LU/LC data for each sample block to generate estimates of LU/LC change for the entire CBARE along with corresponding margins of error at an 85 percent confidence level. A full explanation of Land Cover Trends project methodology is provided by Loveland and others (2002).

\section{Results}

The section that follows illustrates the results of the post classification comparison applied to the five core dates (1973, 1980, 1986, 1992, and 2000) over $36100 \mathrm{~km}^{2}$ sample blocks within the CBARE. Sampling results have been scaled up to the entire CBARE and are reported thusly.

\section{Footprint of Change}

Between 1973 and 2000, the footprint of LU/LC change in the CBARE was 1.45 percent, or $4,978 \mathrm{~km}^{2}$. This change can be interpreted as the amount of the CBARE that experienced change at least once within the study period (and does not account for the frequency of change in any given loca- tion). This overall spatial change translates to $4,370 \mathrm{~km}^{2}$ that changed in one period, $442 \mathrm{~km}^{2}$ that changed in two periods, and $166 \mathrm{~km}^{2}$ that changed in three periods.

\section{Normalized Annual Change}

The normalized annual rate of LU/LC change in the CBARE from 1973 to 2000 was 0.06 percent/year. This means that the region averaged 0.06 percent $\left(206 \mathrm{~km}^{2}\right)$ of change each year in the 27-year study period. However, change was not consistent throughout the study period, but varied greatly between each of the four periods. As a matter of fact, the CBARE experienced a growing rate of change from 1973 to 2000 (fig. 3). Between 1973 and 1980, the annual rate of change in the CBARE was 0.03 percent/year, while the annual rate of change increased to 0.06 percent/year from 1980 to 1986 and 1986 to 1992. The final period, which spanned from 1992 to 2000, experienced an increased rate of change from the preceding periods, up to 0.10 percent/year.

\section{Class Area and Change}

Our results illustrate the dominance of four of the eleven LU/LC classes in the CBARE in 2000: grassland/shrubland (75.38 percent), forest (15.26 percent), natural barren (3.88 percent), and agriculture (2.91 percent). Although the remaining seven classes cumulatively made up the remaining 2.55 percent of the CBARE landscape in 2000, each of these classes made up less than 1 percent of the ecoregion (table 1). Between 1973 and 2000, the LU/LC types that experienced a measurable net change in relation to the total CBARE area include (in descending order) grassland/shrubland (0.57 percent decrease), nonmechanical disturbed ( 0.55 percent increase), forest ( 0.30 percent decrease), developed ( 0.19 percent increase), water ( 0.15 percent increase), mining $(0.14$ percent increase), and wetland (0.14 percent decrease). However, net change is not necessarily the best indicator of within class variability for those classes experiencing spatio-temporal fluctuations (fig. 4). For instance, agriculture may have only experienced a net loss of 0.03 percent from 1973 to 2000, but agricultural lands experienced 0.26 percent gross change in the CBARE in the same period.

\section{Common Conversions}

The "from-to" information afforded by a post classification comparison allowed us to identify LU/LC class conversions and rank these conversions according to their magnitude. Table 2 illustrates the most frequent conversions from 1973 to 2000 in the CBARE. The two most prominent conversions reflect the natural or nonmechanical disturbance of natural land-cover by fire. Cumulatively, the effect of nonmechanical disturbance on grassland, shrubland, and forest resulted 
in $1,872 \mathrm{~km}^{2}$ of vegetated land-cover loss. The transition to and from agriculture and to and from water represent other common conversions in the CBARE. Prominent shifts in agricultural lands include a $527 \mathrm{~km}^{2}$ conversion from grassland/shrubland to agriculture and a $503 \mathrm{~km}^{2}$ from agriculture to grassland/shrubland. Similarly, the water class experienced a variety of conversions within the CBARE: a $602 \mathrm{~km}^{2}$ conversion from wetland to water, a $255 \mathrm{~km}^{2}$ conversion from water to grassland/shrubland, a $222 \mathrm{~km}^{2}$ conversion from grassland/shrubland to water, and a $178 \mathrm{~km}^{2}$ conversion from water to wetland (note: water conversions account for shifts in both natural and manmade water bodies). Ultimately, these agricultural and water conversions illustrate the shifting landuse dynamics across the region. The types of conversions that were predominantly unidirectional and permanent include changes from the grassland/shrubland class to both developed $\left(538 \mathrm{~km}^{2}\right)$ and mining lands $\left(526 \mathrm{~km}^{2}\right)$.

\section{Temporal Change Characteristics}

Throughout the 27-year study period, we measured substantial temporal variability in certain LU/LC classes in the CBARE. Table 3 illustrates these fluctuating conversion rates. In terms of land-use fluctuations, agriculture, water, and mining all experienced measurable within and between period fluctuations from 1973 to 2000. Between 1973 and 1980, the agricultural class averaged a net annual increase of 48.6 $\mathrm{km}^{2} /$ year. During the next two periods, CBARE agriculture averaged an annual decline of $16.4 \mathrm{~km}^{2} /$ year (1980-1986) and $66.1 \mathrm{~km}^{2} /$ year (1986-1992). During the final period from 1992 to 2000 , the rate of agricultural conversions increased to +8.4 $\mathrm{km}^{2} /$ year.

Temporal fluctuations in the water class within periods were not as significant as the agricultural class, but between period fluctuations ranged a great deal. From 1973 to 2000, the rate of water conversions averaged a $6.2 \mathrm{~km}^{2} /$ year decline, but conversions increased to $+151.6 \mathrm{~km}^{2} /$ year from 1980 to 1986. Average water conversions declined by $53.5 \mathrm{~km}^{2} /$ year for the period from 1986 to 1992, and only declined by 3.4 $\mathrm{km}^{2} /$ year from 1992 to 2000 .

Whereas the agricultural and water class averaged major temporal change fluctuations, the mining class followed a general growth trend with the exception of one period. In the first period (1973-1980), mining increased annually by a rate of $4.8 \mathrm{~km}^{2} /$ year. However, the second period from 1980 to 1986 averaged a $1.5 \mathrm{~km}^{2} / \mathrm{year}$ decline. During the final two periods, the rate of mining then increased to an average of $19.7 \mathrm{~km}^{2} / \mathrm{yr}$ from 1986 to 1992 and $44 \mathrm{~km}^{2} /$ year from 1992 to 2000.

Many of the aforementioned fluctuations in land use (along with less variable instances of land use) inversely influenced land-cover in the CBARE. Because grassland/shrubland was the dominant land-cover in the region (75.4 percent), shifts in anthropogenic land use tended to influence this class the most, thus accounting for the considerable within and between period variability. The grassland/shrubland class aver- aged an annual decline of $50 \mathrm{~km}^{2} /$ year from 1973 to 1980 and a decline of $48.5 \mathrm{~km}^{2} / \mathrm{year}$ in the period from 1980 to 1986. During the third period (1986-1992), grassland/shrubland averaged an annual increase of $25.7 \mathrm{~km}^{2} /$ year, which was consistent with the drop in agriculture and water in the same period. In the final period (1992-2000), grassland/shrubland declined by $183.2 \mathrm{~km}^{2} /$ year, predominantly attributable to an increase in the nonmechanically disturbed class (fire).

\section{Change Precision}

LU/LC change estimates for each of the four time periods (1973-1980, 1980-1986, 1986-1992, and 1992-2000) are stated by a margin of error at an 85 percent confidence interval (table 4). Each period had a very low margin of error, well within the Land Cover Trends project precision standard of detecting change at $+/$ - one percent at an 85 percent confidence. However, these small errors are directly related to the small amount of gross change across the CBARE.

\section{Discussion}

The minimal amount of LU/LC change measured in the CBARE between 1973 and 2000 has been primarily influenced by natural forces. The harsh climate, infertile soils, and lack of viable resources have historically impeded human land-use change in the region (Brussard and others, 1998, Pellant and others, 2004, and Chambers and others, 2004). These factors continue to minimize anthropogenic change in the region, despite a variety of drivers encouraging change. The following section details the predominant changes in the CBARE from 1973 to 2000.

\section{Fire}

We found the most significant change in the CBARE from 1973 to 2000 to be a conversion to the nonmechanically disturbed class, entirely from fire. The total amount of change due to fire totaled $1,872 \mathrm{~km}^{2}, 1,005 \mathrm{~km}^{2}$ from forest to nonmechanically disturbed, and $867 \mathrm{~km}^{2}$ from grassland/shrubland to nonmechanically disturbed (fig. 5). These changes, which all occurred from 1992 to 2000, translate to 0.55 percent of change in the CBARE's land area.

In order to evaluate our results for the conversions to the nonmechanical disturbance class, we compared all detected instances of fire with a geospatial dataset of fire perimeters developed by the USGS SAGEMAP Program (SAGEMAP). The SAGEMAP fire database, which was composed using 486 different files on Great Basin fire history, contains regions (polygons) representing fire perimeters between 1870 and 2003 (Finn and others, 2004). Each of the fires captured in our sampling were consistent with fire locations from the SAGEMAP region coverage; however, we did not detect all of the instances of fire within the SAGEMAP dataset in our sample 
blocks. The characteristics of each dataset may account for this discrepancy. For example, our ability to map fire is highly dependant upon factors such as burn area, fire severity, and fire ignition date (given our imagery resolution and temporal design parameters). The SAGEMAP fire database has a suite of its own characteristics that may account for this discrepancy, such as the inconsistency of data combined to form the large database. Despite differences in the total area burned in each time period, the CBARE's trend towards increased fire frequency identified in our research is consistent with the SAGEMAP trend from 1973 to 2000 (fig. 6).

The instances of nonmechanical disturbance within the CBARE over the study period are attributed exclusively to fire. Much like the remainder of the West, fire regimes are a normal phenomenon that accompanies arid climates and an abundance of dry fuel sources. However, fire regimes have changed significantly within the region since Eurasian settlement in the late 1800 s, ultimately contributing to the loss of sagebrush plant communities (Miller and others, 2001). Most notably, livestock grazing and adoption of fire suppression in the CBARE have played a role in the expansion of juniper woodlands (for example, Juniperus communis, Juniperus occidentalis, and Juniperus osteosperma) from upland slopes into sagebrush communities (for example, Artemisia tridentata, Artemisia cana, and Artemisia arbuscula). Prescribed burns have been applied as a method to control juniper expansion, but prescribed fires tend to raise levels of nitrogen for 2 to 3 months following a fire.

Elevated soil nitrogen levels contribute to another problem that plagues the CBARE. Invasive cheatgrass is favored in high-nitrogen conditions over native plants and increases fire frequency in the CBARE by providing a dense and continuous source of fuel that extends the fire season (Pyke, 2002). Frequent fires not only eliminate native sagebrush in the short term from pure destruction, but the competitiveness and prolific seed production of cheatgrass also allows it to reestablish before sagebrush after wildfires occur (Keeley, 2006, Pellant and others, 2004). Cheatgrass has ultimately created a positive feedback mechanism that favors frequent fires and early reestablishment in previously occupied landscapes. Fire records indicate a doubling of fires between 1988 and 1999 (Pyke, 2002). The complex nature of vegetation preservation and fire management in the CBARE continues to perplex land managers, who hope to restore sagebrush communities in a self-sustainable manner.

Increased fire frequency in the CBARE has a wide range of potential consequences beyond the effect on native vegetation. Much of the wildlife that depends on this vegetated landscape may become more vulnerable due to loss of habitat following a fire, but certain species such as the Great Basin pocket mouse (Perognathus parvus) benefit from rapid seed dispersal during post-fire plant succession (Brandt and others, 1994). Fire also threatens human communities and jeopardizes traditional ranging practices in the region (USGS, 2003).

These potential impacts on human and natural systems require a better understanding of the interrelationship between vegeta- tion expansion and fire trends. Although our project design does not lend itself to mapping changes between grassland and shrubland communities, our research can be used in conjunction with existing data on cheatgrass expansion to better understand the interrelationship between vegetation expansion and fire in the CBARE.

\section{Agricultural Conversions}

Although the statistics reflect a small net change (103 $\mathrm{km}^{2}$ decrease) in the agriculture class over the 27-year study period, the total amount of change to and from the agricultural class was quite significant $\left(892 \mathrm{~km}^{2}\right)$. This gross change illustrates the shift in agricultural use across the CBARE. The poor soil quality and low rainfall across the CBARE makes water accessibility a major obstacle to farmers in the region. Our interpretations and field work suggest that agricultural lands more dependent on water (excluding rangeland) tend to be located near riparian segments and/or springs. The locations of other irrigation dependent agricultural lands across the CBARE are dictated by shifts in ground-water pumping and water diversion practices. Water diversions along the Carson, Humboldt, Truckee, and Walker Rivers have shifted to accommodate irrigation demand, municipal water demand, and government mandated water conservation. These shifts have spread agricultural land use into certain areas, and eliminated agriculture in areas that previously thrived. According to the U.S. Department of Agriculture (2005), areas of stimulated agricultural use in the CBARE have experienced growth in alfalfa and beef production (fig. 7).

However, shifting water allocations only account for a portion of the agricultural variability measured in the CBARE. The northeastern portion of the CBARE, which has the greatest concentration of agricultural land in the ecoregion, has experienced a steady decline in agriculture since the adoption of the Conservation Reserve Program (CRP) in 1985 (USDA, 2005). The CRP, which was created to offset agricultural erosion and preserve wildlife habitat, is a voluntary program that offers rental payments and cost-sharing support to farmers willing to halt agricultural production on their land for 10 to 15 years. With growing enrollment in the CRP in recent years, we expect this decline in agriculture to persist into the future.

The potential impacts of these changes in agricultural land use on the environment can be negative or positive in nature. According to the U.S. General Accounting Office (1993), water diversions, agricultural development, and livestock grazing are the major causes of riparian vegetation degradation. The conversion from natural wetlands and riparian (or spring fed) meadows to agriculture alters the ecological and physical properties of riparian areas, thus degrading ecosystems vital to the fitness of many vertebrates and invertebrates. This degradation is manifested as livestock trampling of native vegetation and lowered water tables caused by agricultural and municipal diversions (Brussard and others, 1998). However, irrigation water diversions to areas such as the Smith and Mason Valleys 
may have created artificial habitats conducive to biological diversity (Brussard and others, 1998). Moreover, land being conserved through CRP enrollment has provided a way to reduce the aforementioned degradation to natural vegetation.

\section{Water Conversions}

Between 1973 and 2000, we also detected a measurable change to and from the water class, which is a result of shifting hydrologic regimes in the area generated by regional irrigation demand, municipal water demand, and government mandated water conservation. We estimated $1,257 \mathrm{~km}^{2}$ of gross change in the water class: $602 \mathrm{~km}^{2}$ of land converted to water and $655 \mathrm{~km}^{2}$ of land that converted from water to another class. Many of the reservoirs in the CBARE have experienced surface level fluctuations between 1972 and 2000 (for example, Walker Lake). Although the literature indicates a generally dry climatic trend from 1973 to 2000 (rainfall: 4.9 inches/year), many of the lakes in the western CBARE have nearly zero inflows due to agricultural diversions, which is the primary factor contributing to the drop in lake levels in the western CBARE (Thomas, 1995).

Water fluctuations are both a cause and effect of many issues in the region. Water diversions may support municipal and agricultural growth in the CBARE, but the decline of water resources has caused a clear problem concerning regional fauna that rely on water and riparian vegetation. The significant drop in many reservoirs in CBARE in the 20th century has not only endangered fish populations (for example, cui cui (Chasmistes cujas), tui chub (Gila bicolor), and Lahontan cutthroat trout (Oncorhynchus clarki henshawi)) but also the migratory birds that depend on these fish for survival (Brussard and others, 1998, USGS, 2003). In the Walker Lake area alone, agricultural water diversions along the Walker River have contributed to a rapid drop in lake level, which has increased the concentration of total dissolved solids and jeopardized the health of fish and invertebrate populations (Koch and others 1979). Declining fish populations also translate to a decline in recreational fishing and the elimination of a cultural asset of the Northern Pauite Indians (Brussard and others, 1998, USGS, 2003).

\section{Development}

The CBARE has remained one of the least developed areas in the United States, but our research indicates a trend towards rapid development. Between 1973 and 2000, we detected a 43 percent growth in development across the CBARE, most of which occurred along Interstate-80, Interstate-15, and U.S. Highway-395. This translates to $649 \mathrm{~km}^{2}$ (0.2 percent of the CBARE) of land converted to development, mostly from grassland/shrubland $\left(538 \mathrm{~km}^{2}\right)$. We also noticed an increasing trend in development throughout the 27-year study period. Ultimately, this growth can be attributed to the emigration of people from Pacific states seeking out gaming, recreation, and tourist opportunities, as well as the appeal of tax incentives (no income tax in Nevada). In recent history, the CBARE's service economy has become far more appealing to emigrants than the tradition resource-based economy (Starrs and others, 1996).

These growth trends are consistent with housing unit statistics gathered by the U.S. Census Bureau since 1980 (Geolytics, 2004). The only detectable discrepancy between each of these datasets is the slightly larger growth in housing units (54.6 percent increase) compared to our rate of development (41.1 percent increase) from 1980 to 2000 (fig. 8). This difference may be attributable to the low development density and high percentage of mobile homes in the region, two factors that present a problem when trying to map development using a 60-meter mapping unit. The U.S. Census Bureau's definition of a housing unit may also account for the small discrepancy in growth rates. According to the U.S. Census Bureau (2000), a housing unit can be any place intended for occupancy as separate living quarters, including individual apartments or single rooms. This distinction causes difficulties in comparing housing unit counts to the instances of development identified in our study, as one structure can account for a wide range of housing units.

Much like agricultural waste, municipal waste from development poses a threat to wildlife in the CBARE (fig. 9). Additionally, development creates landscapes that are not used by most native species. Finally, growing regional development leads to an increase in resource consumption, such as municipal and agricultural water demand. Local population growth is directly related to regional demand for raw materials. Therefore, development often dictates how other land useclasses change throughout time and is partially responsible for any of the potential implications affiliated with water and mineral resource use.

\section{Mining}

Like the growth of development in the ecoregion, growth in regional mining comprises a small segment of the LU/LC in the CBARE, but has grown considerably throughout the 27year study period. Although the change in mining only reflects a 0.1 percent change in the CBARE's land area from 1973 to 2000 , regional mining has increased by 158 percent (498 $\mathrm{km}^{2}$ ) throughout the study period. However, we found that the growth in mining has not been consistent between 1973 and 2000. For example, we observed a net decrease in mining from 1980 to 1986 , followed by a 35 percent increase from 1986 to 1992 and a 77 percent increase from 1992 to 2000.

Fluctuations in mining production tend to occur with fluctuations in the price of gold and government regulation (Nevada is the third largest gold producer in the world), which dictate mining plans and the rate of exploration activity in the CBARE (Moyer, 2004). The mining growth in the final two periods can be attributed to the rapid investment in mining 
plants, equipment, and exploration since 1980, totaling over $\$ 10$ billion in Nevada alone (University of Nevada Reno, 1999) (fig. 10).

One of the most significant implications of mining in the CBARE is the long-term contamination of lands inhabited by wildlife and humans. The effect of historical mining in the region is well-documented and continues to be a problem (Lechler and others, 1997, Shevenell, 2000). For example, a large portion of the Carson River is designated as an EPA Superfund Site due to the mercury contamination while mining gold and silver during the Comstock Lode (1860-1890). Recent gold mining also poses an environmental threat. For example, a large number of migratory birds were killed from the mid1980s through the early 1990s from cyanide contamination at Nevada gold mines (USGS, 2003). Other species directly impacted by toxin contamination include many bat species that roost in old mine shafts and fish populations located in areas of water contamination (Brussard and others, 1998). The bioaccumulation of mining-related toxins in the food chain also has potential implications on other wildlife and humans.

\section{Conclusion}

Contemporary land-use/land-cover change has been very minimal throughout the CBARE. However, the results of our analysis indicate that these landscape changes resulting from increased fire frequency, rising demand for water and mineral resources, and growing highway development can have far-reaching consequences despite the small spatial extent of change. Although wildlife has proven to be resilient to anthropogenic land use, the loss of natural vegetation due to the aforementioned changes has both eliminated and polluted ecosystems utilized by endangered species such as the sage grouse (Centrocercus urophasianus). Moreover, certain trends such as increased fire frequency in the CBARE have the potential to harm human populations as well. The growth of human populations in the Reno-Sparks and Salt Lake City-Odgen metro areas will likely dictate the rate of future land-use conversions in the CBARE, either encouraging public land management agencies to preserve natural vegetation or continuing with current resource extraction practices. These findings can be used in conjunction with existing literature to explore how and to what extent current land-use/land-cover trends will impact the CBARE into the future and may provide insights into how policy change may change current landscape conditions.

\section{References}

Anderson, J.P., Hardy, E.E., Roach, J.T., and Witmer, R.E., 1976, A land use and land cover classification system for use with remote sensor data: U.S. Geological Survey Professional Paper $964,28 p$.
Billings, W.D., 1951, Vegetational zonation in the Great Basin of western North America: International Union of Biological Sciences, Series B, no. 9 .

Brandt, C.A., and Rickard, W.H., 1994, Alien taxa in the North American shrub-steppe four decades after cessation of livestock grazing and cultivation agriculture: Biological Conservation, v. 62 , no. 2 , p. $95-105$.

Brussard, P.F., Charlet, D.A., Dobkin, D.S., Ball, L.C., Bishop, K.A., Britten, H.B., Fleishman, E., Fleury, S.C., Jenni, T., Kennedy, T.B., Mullen, C.O., Peacock, M.M., Prusso, D., Reed, M., Riley, L., Rust, R.W., Simpkin, J.L., Vinyard, G., Yandell, U.G., Marlow, R., and Charlet, D.A., 1998, Great Basin-Mojave Desert Region, in Mac, M.J., Opler, P.A., Puckett Haeker, C.E., and Doran, P.D., eds., Status and trends of the nation's biological resources: Reno, Nevada, U.S. Geological Survey, v. 2 [http://biology.usgs.gov/s+t/SNT/noframe/gb150.htm (last accessed February 2, 2006)].

Bureau of Economic Analysis, 2000, Bureau of Economic Analysis Regional Economic Information System [http:// www.bea.gov/bea/regional/data.htm (last accessed October 15, 2006)].

Chambers, J.C., and Miller, J.R., 2004, Great Basin riparian areas; ecology, management, and restoration: Society for Ecological Restoration International: Washington, D.C., Island Press, 303p.

County Business Patterns, 1997, University of Virginia, Geospatial and Statistical Data Center [http://fisher.lib.virginia. edu/collections/stats/cbp/ (last accessed October 15, 2006)].

Eiswerth, M.E., and Shonkwiler, J.S., 2006, Examining post-wildfire reseeding on arid rangeland: A multivariate tobit modelling approach: Ecological Modeling, v. 192, p. 286-298.

Environmental Protection Agency, 1999, Level III Ecoregions of the Continental United States: Corvallis, Oregon, U.S. Environmental Protection Agency, National Health and Environmental Effects Research Laboratory, scale $1: 7,500,000$.

Finn, S.P., Hanser, S.E., Meinke, C.W., and Smith, A., 2004, The Great Western Fire Map (<=2003) [http://sagemap. wr.usgs.gov/ftp/regional/USGS/Fires_WNA.zip (last accessed July 7, 2005)].

GeoLytics, Inc., 2004, Housing Unit Database 1980-2000 Block Group Data: East Brunswick, New Jersey, GeoLytics, Inc.

Grayson, D.K., 1993, The desert's past; a natural prehistory of the Great Basin: Washington, D.C., Smithsonian Institution Press, 356 p. 
Keeley, J.E., 2006, Fire management impacts on invasive plants species in the Western United States: Conservation Biology, v. 20, p. 375-384.

Koch, D.L., Cooper, J.J., Lider, E.L., Jacobson, R.L., and Spencer, R.J., 1979, Investigations of Walker Lake, Nevada; dynamic ecological relationships: Reno, Nevada, Bioresources Center, Desert Research Institute, University of Nevada at Reno, 189 p.

Launius, R.D., 2004, History to Go, Utah History Encyclopedia, State of Utah [http://historytogo.utah.gov/utah_chapters/from_war_to_war/worldwar2inutah.html (last accessed May 25, 2006)].

Lechler, P.J., Miller, J.R., Hsu, L.C., and Desilets, M.O., 1997, Mercury mobility at the Carson River Superfund Site, westcentral Nevada, USA; Interpretation of mercury speciation data in mill tailings, soils, and sediments: Journal of Geochemical Exploration, v. 58, p. 259-267.

Loveland, T.R., Sohl, T.L., Stehman, S.V., Gallant, A.L., Sayler, K.L., and Napton, D.E., 2002, A strategy for estimating the rates of recent United States land-cover changes: Photogrammetric Engineering and Remote Sensing, v. 68, no. 10, p. 1091-99.

Miller, R., Baisan, C., Rose, J., and Pacioretty, D., 2001, Preand post-settlement fire regime in mountain big sagebrush steppe and aspen: the northwestern Great Basin: Corvallis, Oregon, National Interagency Fire Center.

Moyer, L.A., 2004, Mining activity in Nevada, 1851-1995: U.S. Geological Survey Open File Report 2004-1244 [http:// pubs.usgs.gov/of/2004/1244/ (last accessed July 14, 2006)].

National Atlas of the United States, 2005, Cities and Towns of the United States [http://www.nationalatlas.gov/atlasftp. html\#citiesx (last accessed October 15, 2006)].

National Atlas of the United States, 2005, Federal Lands of the United States [http://www.nationalatlas.gov/atlasftp. html\#fedlanp (last accessed October 15, 2006)].

Noss, R.F., LaRoe, E.T., III, and Scott, J.M., 1995, Endangered ecosystems of the United States; a preliminary assessment of loss and degradation: National Biological Service Biological Report 28, 58 p.

Omernik, J.M., 1987, Ecoregions of the conterminous United States: Annals of the Association of American Geographers, v. 77 , p. 118-125.

Pellant, M., Abbey, B., and Karl, S., 2004, Restoring the Great Basin Desert, U.S.A.; integrating science, management, and people: Environmental Modeling and Assessment, v. 99, p. 169-179.
Pyke, D.A., 2002, Born of fire-restoring sagebrush steppe: U.S. Geological Survey Forest and Rangeland Ecosystem Science Center, Fact Sheet 126-02, 2 p.

Rogers, G.F., 1982, Then and now: a photographic history of vegetation change in the central Great Basin desert: Salt Lake City, Utah, University of Utah Press.

Rowland, M.M., Wisdom, M.J., Suring, L.H., and Meinke, C.W., 2006, Greater sage-grouse as an umbrella species for sagebrush-associated vertebrates: Biological Conservation, v. 129, p. 323-335.

Shevenell, L., 2000, Water quality in pit lakes in disseminated gold deposits compared to two natural, terminal lakes in Nevada: Environmental Geology, v. 39, no. 7, p. 807-815.

Starrs, P.L., and Wright, J.B., 1996, Great Basin growth and the withering of California's pacific idyll: The Geographical Review, v. 85, no. 4, p. 417-435.

Thomas, J., 1995, Water budget and salinity of Walker Lake, western Nevada: U.S. Geological Survey Fact Sheet 115-95, 4 p.

Trimble, S., 1989, The Sagebrush Ocean: A Natural History of the Great Basin: Reno, Nevada, University of Nevada Press.

U.S. Census Bureau, 2000, Glossary of Decennial Census terms and acronyms [http://www.census.gov/main/www/ glossary.html (last accessed January 14, 2006)].

U.S. Census Bureau, 2000, American Fact Finder [http://fact finder.census.gov/home/saff/main.html?_lang=en (last accessed January 14, 2006)].

U.S. Department of Agriculture, 2005, National Agricultural Statistical Service (NASS): United States Department of Agriculture, National Agricultural Statistics Service, Research and Development Division, Geospatial Information Branch [http://www.nass.usda.gov/ last accessed October 13, 2006)].

U.S. General Accounting Office, 1993, Livestock grazing on western riparian areas: Gaithersburg, Maryland, $44 \mathrm{p}$.

U.S. Geological Survey, 2003, Biological science in the Great Basin: Seattle, Washington, U.S. Geological Survey Forest and Rangeland Ecosystem Science Center, Western Region Briefing Paper, 2 p.

University of Nevada at Reno, 1999, Trends in the mining industry; Reno, Nevada, State of Nevada and Eureka County: University of Nevada at Reno, 4 p.

Wisdom, M.J., Suring, L.H., Rowland, M.M., Tausch, R.J., Miller, R.F., Schueck, L., Wolff Meinke, C., Knick, S.T., and Wales, B.C., 2003, A prototype regional assessment of habitats for species of conservation concern in the Great Basin Ecoregion and State of Nevada; chapter 5: La Grande, Oregon, USDA Forest Service, Pacific Northwest Research Station, Version 1.1, unpub. report on file. 


\section{Appendix. Definitions of Land Use and Land Cover}

The following are the general land-cover definitions that will be used in the project. To the extent possible, the definitions are based on the original Anderson and others (1976) level I definitions so that land-cover data developed through the Land Cover Trends project are consistent with those produced through other programs and projects. A minimum mapping unit of 60 meters will used to determine land-cover.

Developed - Areas of intensive use with much of the land covered with structures (for example, high density residential, commercial, industrial, or transportation) or less intensive uses where the land-cover matrix includes both vegetation and structures (for example, low density residential, recreational facilities, cemeteries, or transportation and utility corridors), including any land functionally related to the developed or built-up activity.

Cropland and Pasture - Land in either a vegetated or unvegetated state used for the production of food and fiber. This includes cultivated and uncultivated croplands, hay lands, pasture, orchards, vineyards, and confined livestock operations. Note that forest plantations are considered as forests or woodlands regardless of the use of the wood products.

Forests and Woodland - Tree-covered land where the tree-cover density is greater than 10 percent. Note that cleared forest land (for example, clearcuts) will be mapped according to current cover (for example, disturbed or transitional, shrubland/grassland).

Shrubland/Grassland - Land predominately covered with grasses, forbs, or shrubs. The vegetated cover must be at least 10 percent of the area.
Wetland - Lands where water saturation is the determining factor in soil characteristics, vegetation types, and animal communities. Wetlands are comprised of water and vegetated cover.

Water Bodies - Areas persistently covered with water, such as streams, canals, lakes, reservoirs, bays, or oceans.

Snow and Ice - Land where the accumulation of snow and ice does not completely melt during the summer period.

Natural Barren - Land comprised of natural occurrences of soils, sand, or rocks where less than 10 percent of the area is vegetated.

Mined Lands - Areas with extractive mining activities that have a significant surface expression. This includes (to the extent that these features can be detected) mining buildings, quarry pits, overburden, leach, evaporative, tailing, or other related components.

Mechanical Disturbed or Transitional - Land in an altered unvegetated state that, due to disturbances by mechanical means, is in transition from one cover type to another. Mechanical disturbances including forest clear cutting, earthmoving, scraping, chaining, reservoir draw down, or other related human-induced changes.

Nonmechanical Disturbed or Transitional - Land in an altered unvegetated state that, due to disturbances by nonmechanical means, is in transition from cover type to another. Nonmechanical disturbances include wind, floods, fire, animals, and other related sources. 


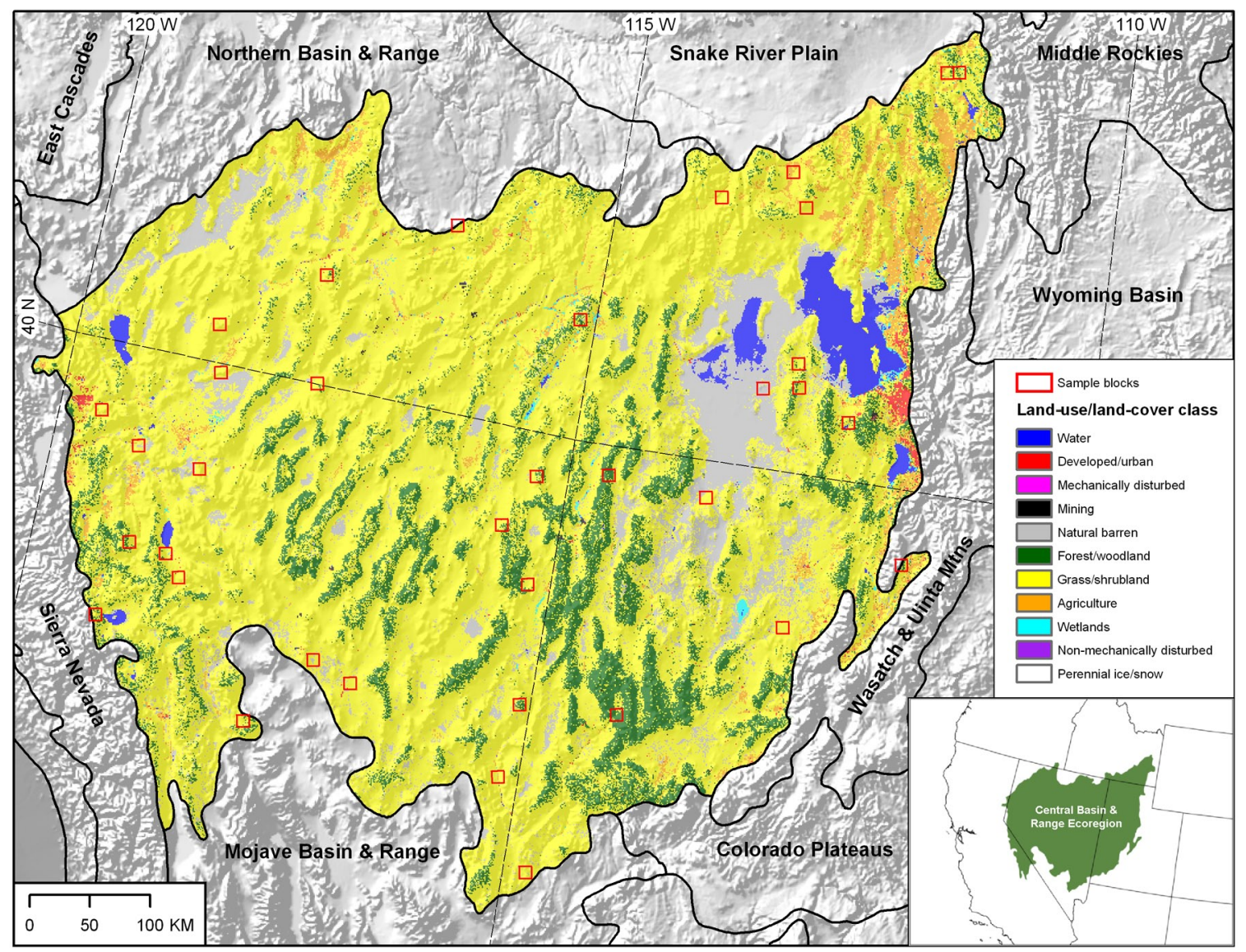

Figure 1. Central Basin and Range ecoregion. Information shown for the Central Basin and Range ecoregion includes land use/land cover from the 1992 National Land Cover Dataset and the 36 randomly selected $100 \mathrm{~km}^{2}$ sample blocks. 


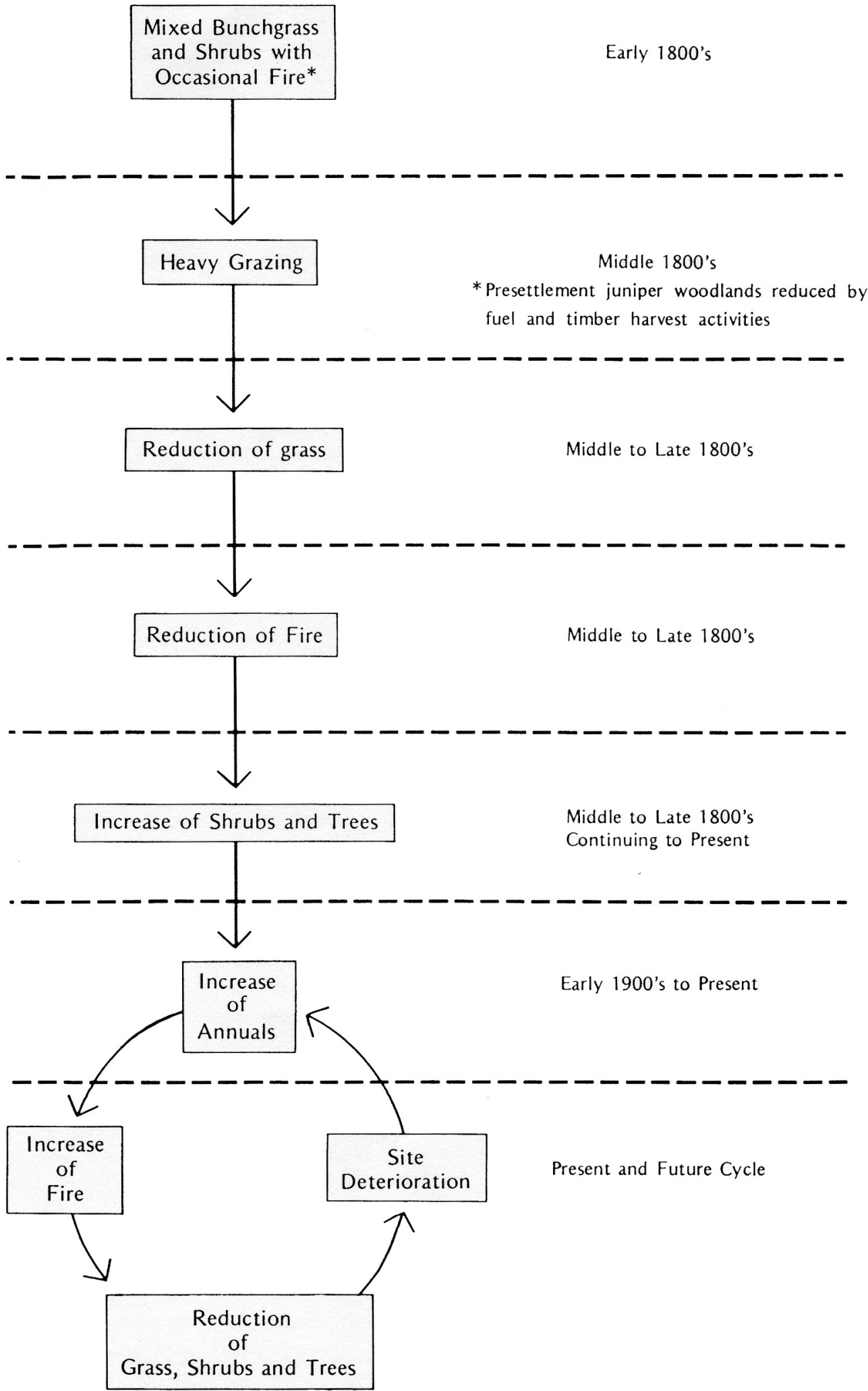

Figure 2. Historical and present interrelationships between land use, invasive plants, and fire in the Central Basin and Range ecoregion (from Rogers, 1982). 


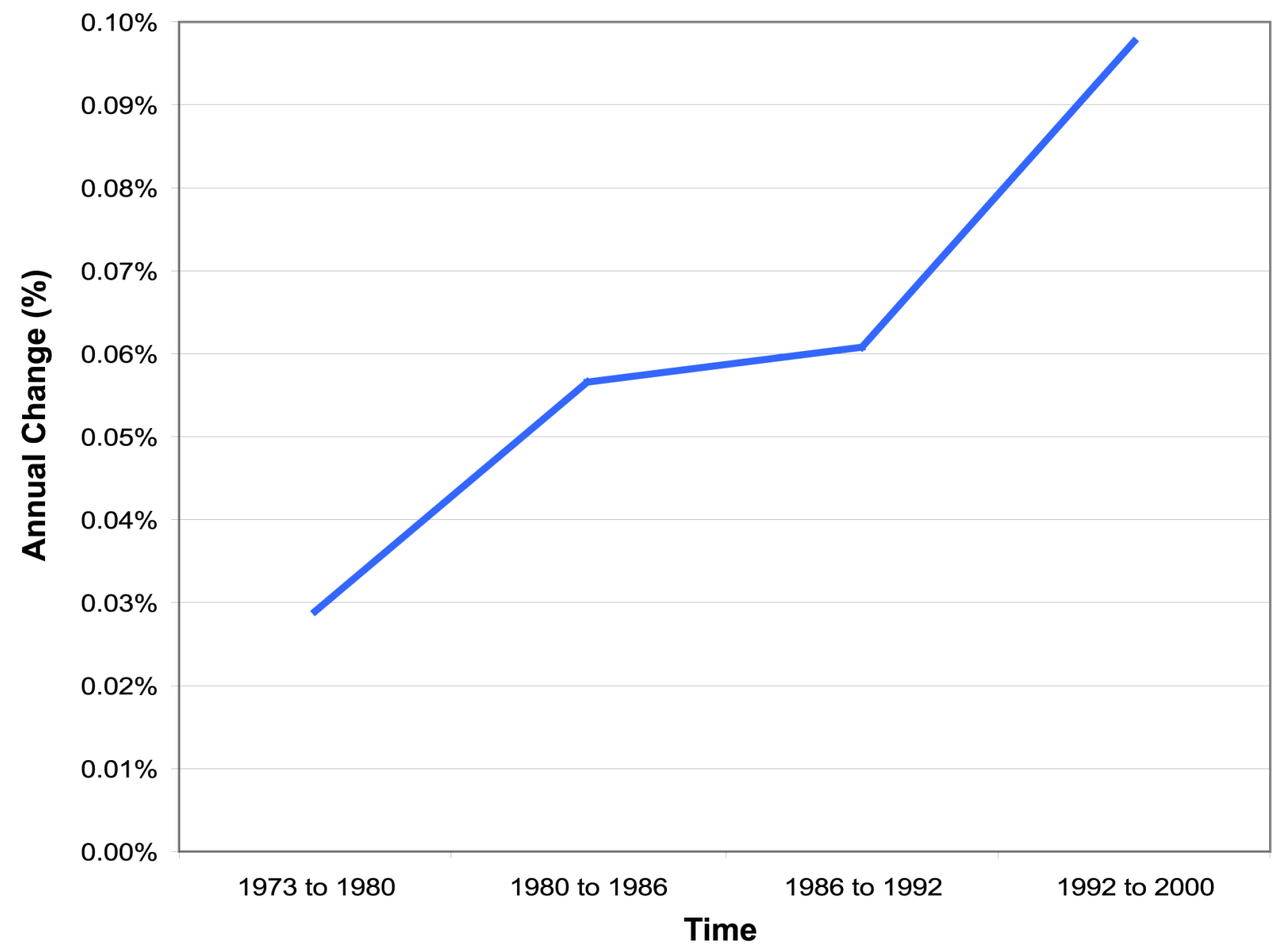

Figure 3. Average annual rates of change by period for the Central Basin and Range ecoregion. 


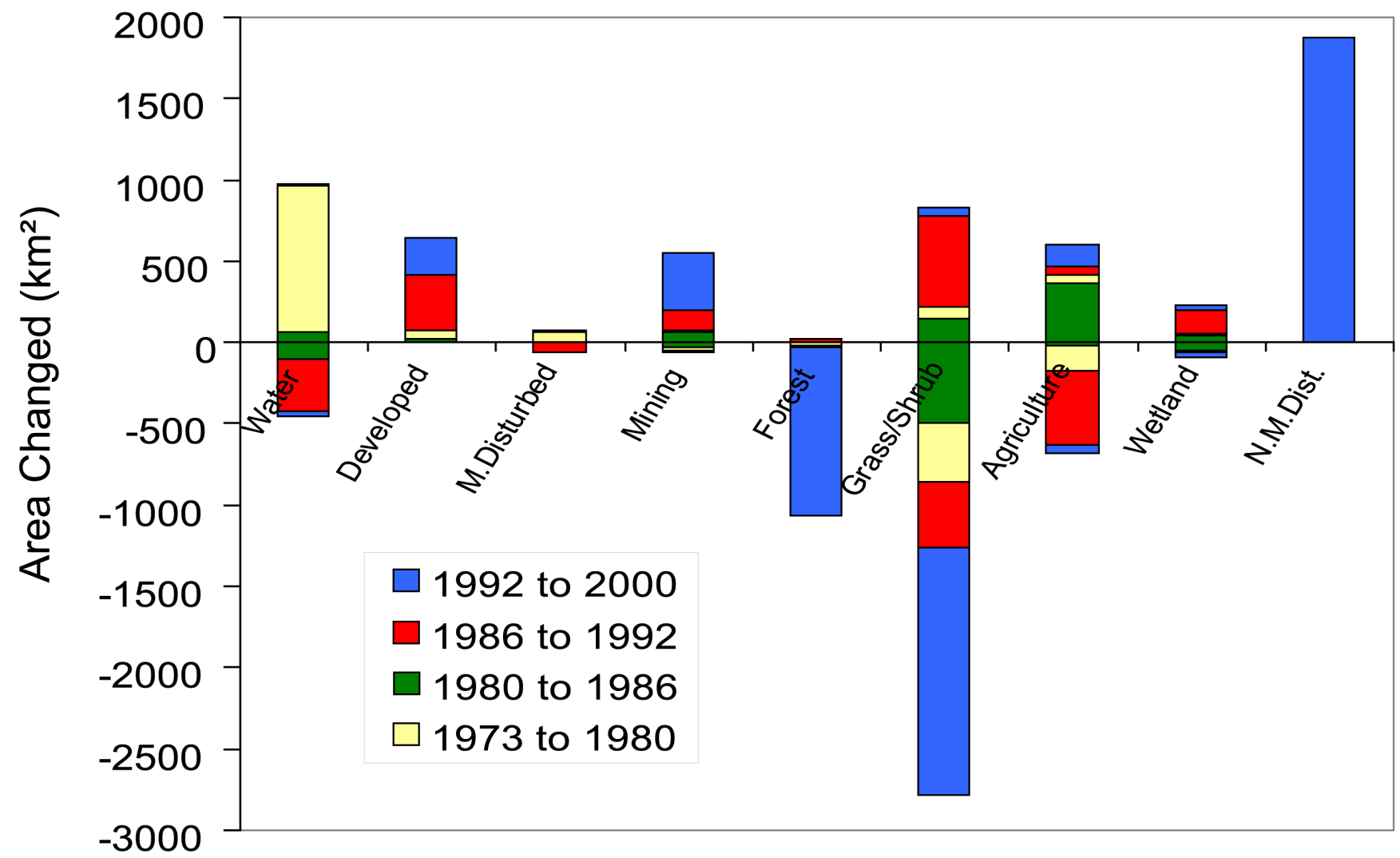

Figure 4. Gross change in land use/land cover for each of the four periods studied for the Central Basin and Range ecoregion. Illustrates within class fluctuations for each period. 


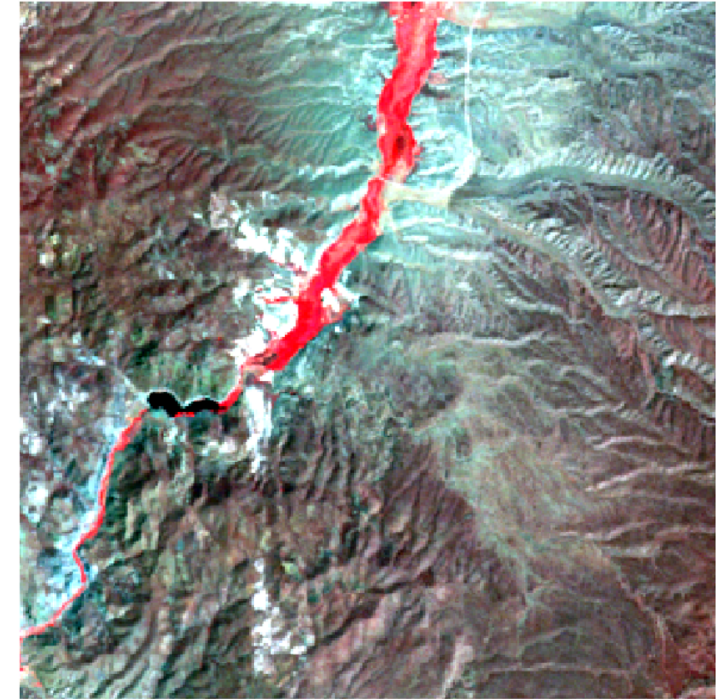

1992 Landsat TM

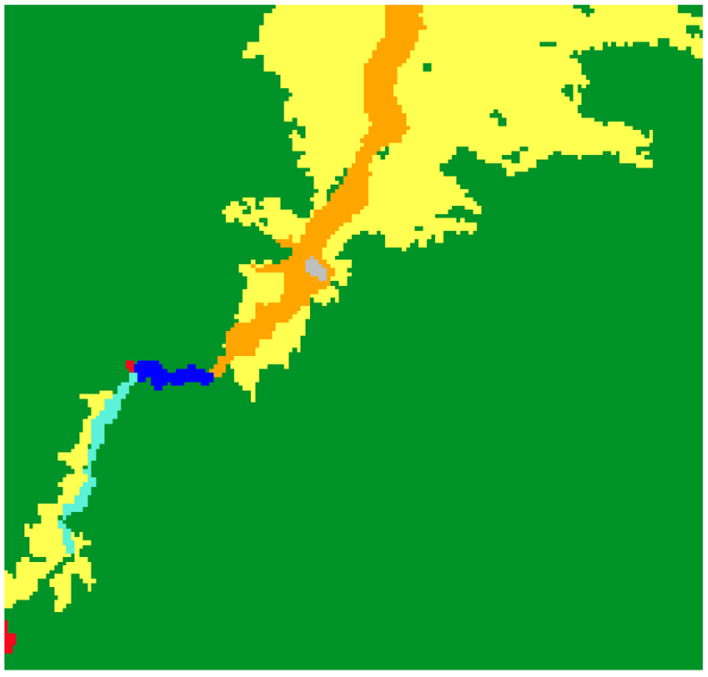

1992 Land-Use/Land-Cover Data

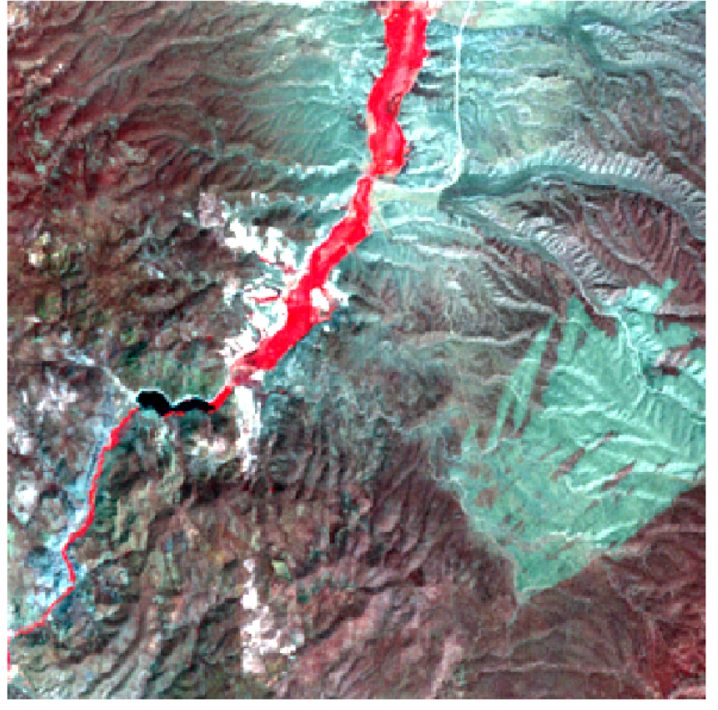

2000 Landsat ETM+

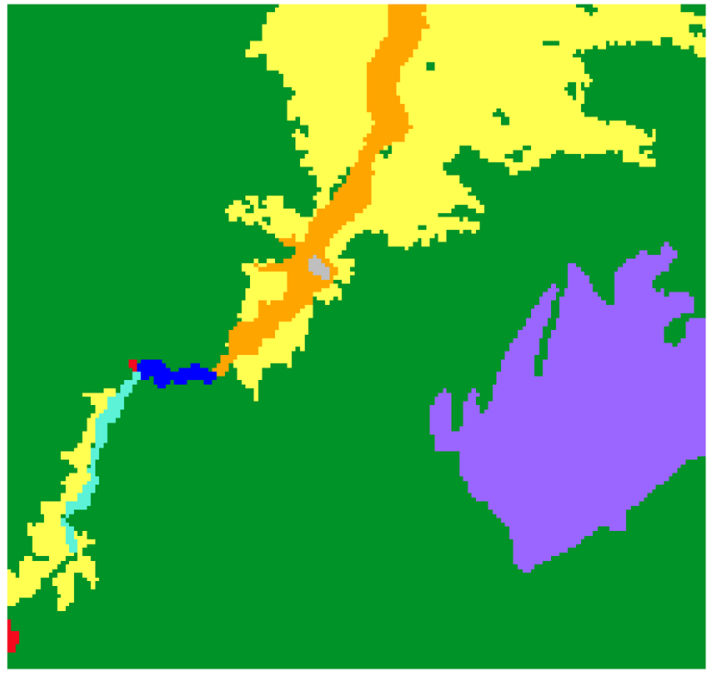

2000 Land-Use/Land-Cover Data

Figure 5. An example of nonmechanically disturbed (NMD) in the period from 1992-2000. NMD, which is entirely attributable to fire in the Central Basin and Range ecoregion, is shown in the 2000 land-use/landcover data as purple. 


\section{Fires in the Central Basin and Range Ecoregion}

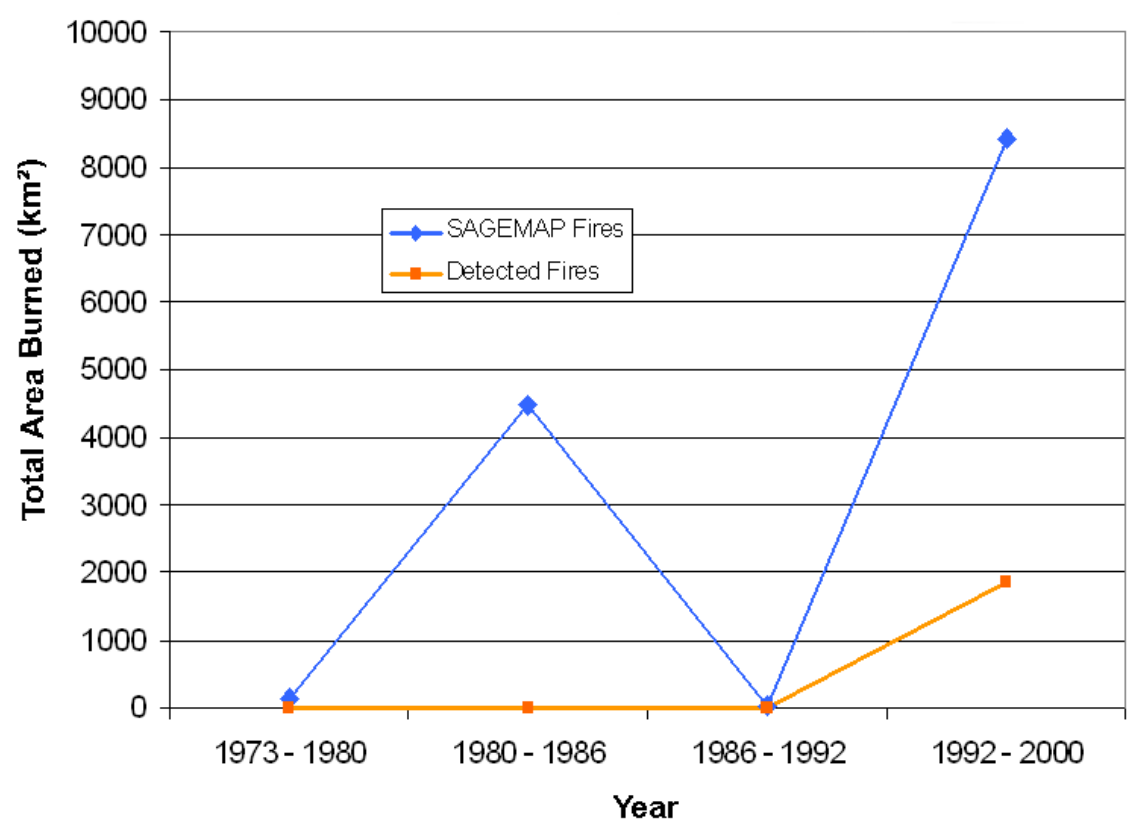

Figure 6. Amount of area burned $\left(\mathrm{km}^{2}\right)$ between 1973 and 2000. Comparison between U.S. Geological Survey SAGEMAP fire database and our results for the Central Basin and Range ecoregion. 


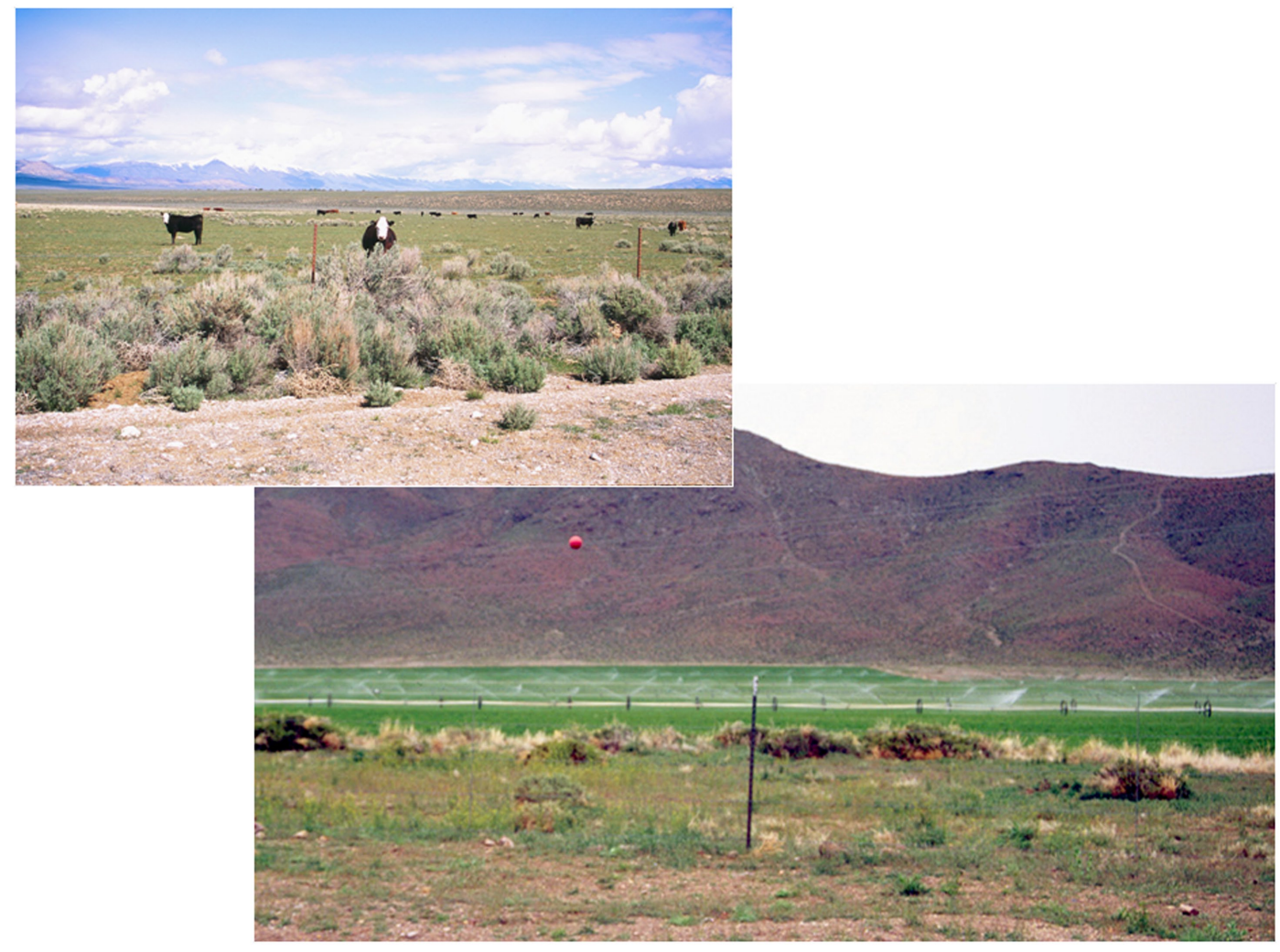

Figure 7. Field photos illustrating instances of agriculture in the Central Basin and Range ecoregion. Upper left picture shows livestock grazing on rangeland, whereas lower right picture shows irrigated fields growing livestock feed.

\section{Development in the CBARE}

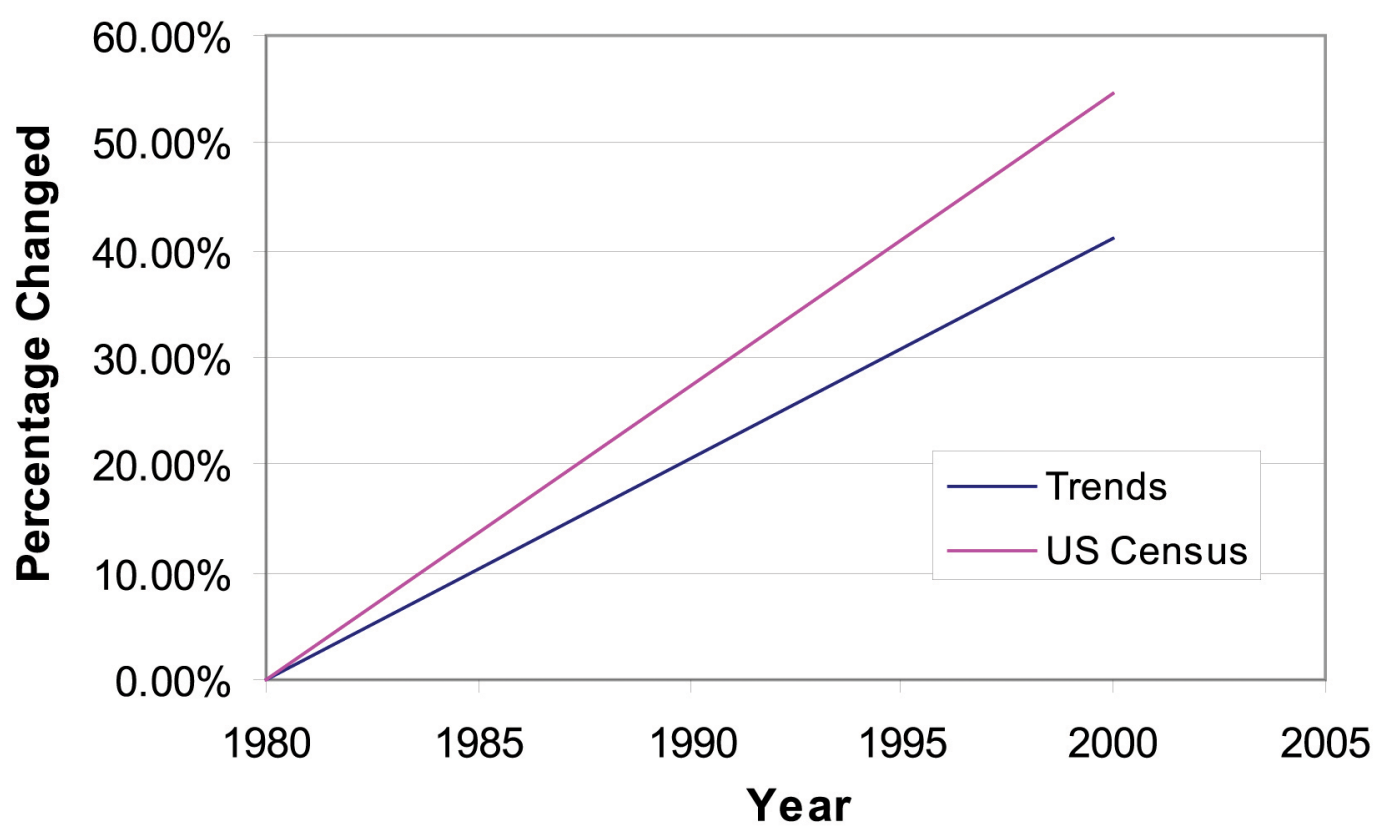

Figure 8. Rate of development in the Central Basin and Range ecoregion between 1980 and 2000. Comparison between U.S. Census data and our results. 

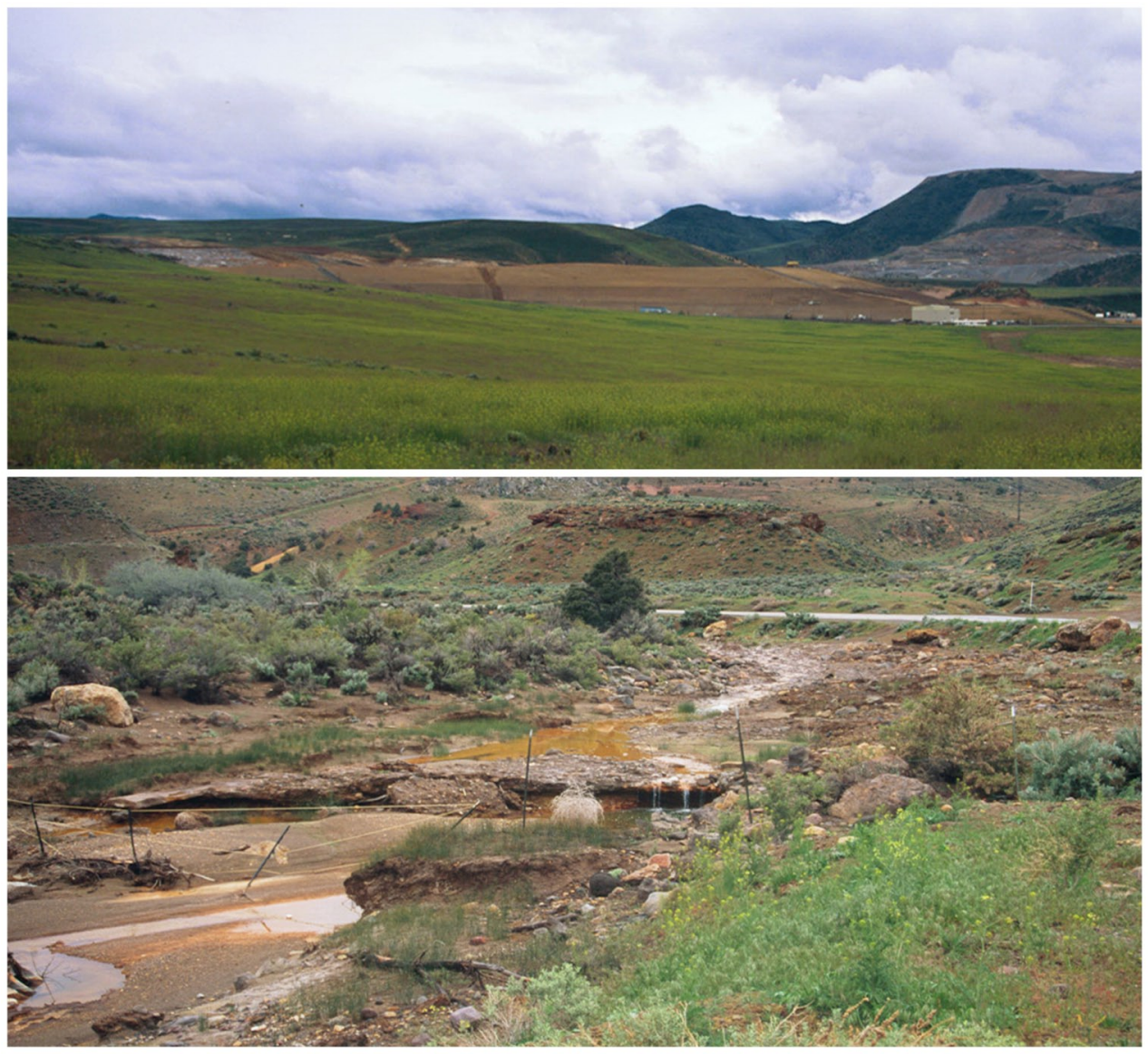

Figure 9. Hillside municipal waste facility and downhill stream drainage near Lockwood, Nevada. 

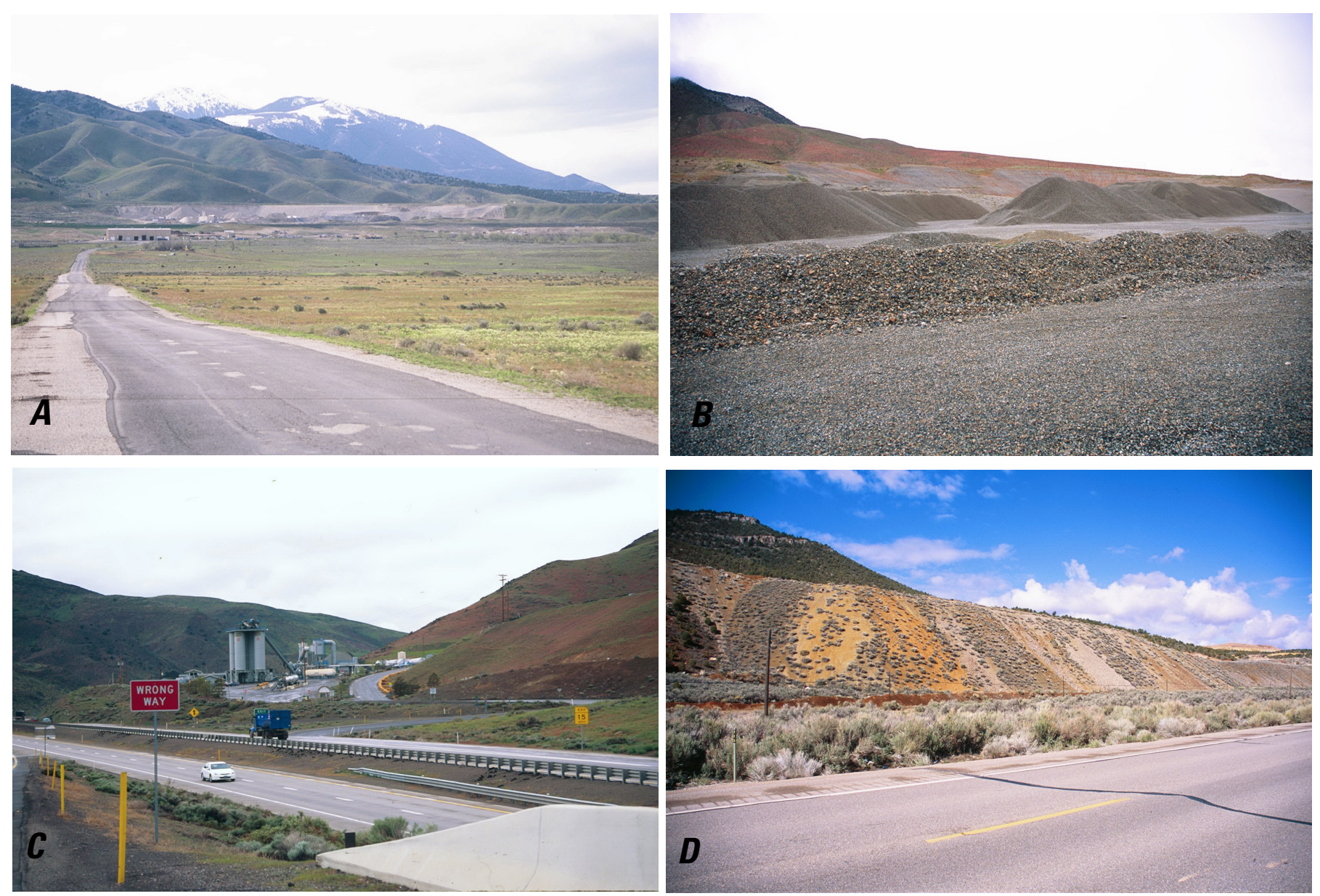

Figure 10. Graphic showing the different elements of mining in the Central Basin and Range ecoregion. $A$, Gravel extraction site near Tooele, Utah; $B$, Piles of gravel aggregate awaiting transport; $C$, Mineral processing facility along Interstate 80 near Reno, Nevada; and $D$, an old tailing pile undergoing reestablishment of vegetation. 
Table 1. Each thematic land-use/land-cover class for the five study dates, as a percentage of Central Basin and Range ecoregion area.

\begin{tabular}{|c|c|c|c|c|c|}
\hline LU/LC CLASS & $\mathbf{1 9 7 3}$ & $\mathbf{1 9 8 0}$ & $\mathbf{1 9 8 6}$ & $\mathbf{1 9 9 2}$ & $\mathbf{2 0 0 0}$ \\
\hline Water & $0.09 \%$ & $0.08 \%$ & $0.34 \%$ & $0.25 \%$ & $0.24 \%$ \\
\hline Developed & $0.44 \%$ & $0.45 \%$ & $0.46 \%$ & $0.56 \%$ & $0.63 \%$ \\
\hline MD & $0.00 \%$ & $0.00 \%$ & $0.02 \%$ & $0.00 \%$ & $0.00 \%$ \\
\hline Mining & $0.09 \%$ & $0.10 \%$ & $0.10 \%$ & $0.13 \%$ & $0.23 \%$ \\
\hline NB & $3.88 \%$ & $3.88 \%$ & $3.88 \%$ & $3.88 \%$ & $3.88 \%$ \\
\hline Forest & $15.56 \%$ & $15.56 \%$ & $15.56 \%$ & $15.56 \%$ & $15.26 \%$ \\
\hline Grass/Shrub & $\mathbf{7 5 . 9 4 \%}$ & $\mathbf{7 5 . 8 4 \%}$ & $\mathbf{7 5 . 7 6 \%}$ & $\mathbf{7 5 . 8 0 \%}$ & $\mathbf{7 5 . 3 8 \%}$ \\
\hline Agriculture & $2.93 \%$ & $3.03 \%$ & $3.00 \%$ & $2.89 \%$ & $2.91 \%$ \\
\hline Wetland & $1.02 \%$ & $1.02 \%$ & $0.85 \%$ & $0.89 \%$ & $0.89 \%$ \\
\hline NMD & $0.00 \%$ & $0.00 \%$ & $0.00 \%$ & $0.00 \%$ & $0.55 \%$ \\
\hline Ice/Snow & $0.04 \%$ & $0.04 \%$ & $0.04 \%$ & $0.04 \%$ & $0.04 \%$ \\
\hline
\end{tabular}

[MD-mechanically disturbed, NB-natural barren, and NMD-nonmechanically disturbed]

Table 2. Most common land-use/land-cover conversions throughout the 27-year study period for the Central Basin and Range ecoregion.

\begin{tabular}{|c|c|c|}
\hline $\mathbf{1 9 7 3}$ to 2000 & & TO \\
\hline AREA (km $\left.\mathbf{~}^{\mathbf{2}}\right)$ & FROM & Nonmechanically Disturbed \\
\hline 1005 & Grassland/Shrubland & Nonmechanically Disturbed \\
\hline 867 & Wetland & Water \\
\hline 640 & Grassland/Shrubland & Developed \\
\hline 538 & Grassland/Shrubland & Agriculture \\
\hline 527 & Grassland/Shrubland & Mining \\
\hline 526 & Agriculture & Grassland/Shrubland \\
\hline 503 & Water & Grassland/Shrubland \\
\hline 255 & Grassland/Shrubland & Water \\
\hline 222 & Water & Wetland \\
\hline 178 & &
\end{tabular}


Table 3. Average annual gains and losses by land-use/land-cover class for the Central Basin and Range ecoregion.

\begin{tabular}{|c|c|c|c|c|}
\hline Rates measured in $\mathrm{km}^{2} / \mathrm{year}$ & 1973-1980 & $1980-1986$ & 1986-1992 & $1992-2000$ \\
\hline \multicolumn{5}{|l|}{ Water } \\
\hline Losses & -14.6 & 0.0 & -53.8 & -3.4 \\
\hline Gains & 8.5 & 151.6 & 0.2 & 0.0 \\
\hline Net change (gains minus losses) & -6.2 & 151.6 & -53.5 & -3.4 \\
\hline \multicolumn{5}{|l|}{ Developed } \\
\hline Gains & 2.8 & 8.5 & 56.9 & 29.6 \\
\hline \multicolumn{5}{|l|}{ Mechanically disturbed } \\
\hline Losses & 0.0 & 0.0 & -10.1 & 0.0 \\
\hline Gains & 0.0 & 10.1 & 0.0 & 1.5 \\
\hline Net change (gains minus losses) & 0.0 & 10.1 & -10.1 & 1.5 \\
\hline \multicolumn{5}{|l|}{ Nonmechanically disturbed } \\
\hline Gains & 0.0 & 0.0 & 0.0 & 234.0 \\
\hline \multicolumn{5}{|l|}{ Forest } \\
\hline Losses & 0.0 & -3.9 & -0.3 & -129.2 \\
\hline Gains & 0.0 & 0.0 & 3.1 & 0.0 \\
\hline Net change (gains minus losses) & 0.0 & -3.9 & 2.7 & -129.2 \\
\hline \multicolumn{5}{|l|}{ Grass/Shrubland } \\
\hline Losses & -70.6 & -60.3 & -68.1 & -189.4 \\
\hline Gains & 20.6 & 11.8 & 93.8 & 6.2 \\
\hline Net change (gains minus losses) & -50.0 & -48.5 & 25.7 & -183.2 \\
\hline \multicolumn{5}{|l|}{ Agriculture } \\
\hline Losses & -3.3 & -25.6 & -75.2 & -7.2 \\
\hline Gains & 51.9 & 9.2 & 9.1 & 15.6 \\
\hline Net change (gains minus losses) & 48.6 & -16.4 & -66.1 & 8.4 \\
\hline \multicolumn{5}{|l|}{ Mining } \\
\hline Losses & -4.1 & -3.1 & -1.3 & -0.6 \\
\hline Gains & 8.9 & 1.6 & 21.0 & 44.6 \\
\hline Net change (gains minus losses) & 4.8 & -1.5 & 19.7 & 44.0 \\
\hline \multicolumn{5}{|l|}{ Wetland } \\
\hline Losses & -7.1 & -0.9 & -0.1 & -5.0 \\
\hline Gains & 6.5 & 1.0 & 24.9 & 3.4 \\
\hline Net change (gains minus losses) & -0.5 & 0.1 & 24.8 & -1.6 \\
\hline
\end{tabular}

Table 4. Gross change and corresponding margin of error for each time period for the Central Basin and Range ecoregion.

\begin{tabular}{|c|c|c|}
\hline Period & Gross Change & $85 \%$ Confidence Interval \\
\hline 1973 to 1980 & $0.20 \%$ & $+/-0.144 \%$ \\
\hline 1980 to 1986 & $0.34 \%$ & $+/-0.346 \%$ \\
\hline 1986 to 1992 & $0.37 \%$ & $+/-0.183 \%$ \\
\hline 1992 to 2000 & $0.78 \%$ & $+/-0.571 \%$ \\
\hline
\end{tabular}

